\title{
Is the Motive for Remittance Static or Dynamic? Altruism vs. Self-interest
}

\author{
Niroshani Anuruddika Kumari Parahara Withanalage and Nada Kulendran* \\ Institute of Sustainable Industries and Liveable Cities, Victoria University, Australia ${ }^{1}$
}

\begin{abstract}
Studies have examined whether remittance is altruistic, self-interested or both. However, there has been little attention on whether it's static or dynamic. This study selected Sri Lanka to fill this gap and used recursive estimates to examine the dynamic nature of remittance. It found that motive for remittance to Sri Lanka has changed. Altruism dominated until 1991, followed by self-interest. ARDL analysis confirmed per capita GDP and government stability as long-run, and accountability and socioeconomic status as short-run, determinants. This study is important for policy in developing countries as it proved the significance of government stability.
\end{abstract}

Keywords: Foreign remittance, altruistic motive, self-interest motive, political risk.

\section{INTRODUCTION}

Understanding what motivates remittance and whether the motive is static or dynamic, despite changes in economic and social factors, are important aspects for policy development. Because different motives for remittance lead to a different remittance aggregates, and the development impact of remittance would varies depending upon the motive for remittance.

The motive for foreign remittance has been studied to a considerable extent inboth micro- and macro-economic contexts (Agarawal and Horowitz, 2002; Henry et al. 2009; Lueth and Arranz 2007; Fonchamnyo, 2012). However, no study has examined the dynamic nature of motive for foreign remittance except Abdin and Erdal (2016). Their study was based on remittance-sending Pakistani taxi-drivers and they found that an electricity crisis in Pakistan in 2007 changed the motive from self-interest to altruism.

Given the relative paucity of academic studies in this area, this study will assess whether the motive for remittance is static or dynamic based on changes of remittance determinants in an aggregate macroeconomic platform. Further this study will examine whether and how political risk could cause inflow of foreign remittance. To do this, we will examine the motive for remittance in Sri Lanka over the period of 1984 to 2016. This study hypothesized that motive for foreign remittance to a country is dynamic over time.

According to the results, per capita gross domestic product (per capita GDP) and government stability are the

*Address correspondence to this author at Institute for Sustainable Industries and Liveable Cities, Victoria University, Melbourne Australia. E-mail: Niroshani.Paraharawithanalage@live.vu.edu.au

Second Affiliation: Niroshani: Faculty of commerece and Management Studies, University of Kelaniya, Sri Lanka. determinants of foreign remittance in the long run, and accountability and socioeconomic status are the short-run determinants. This study contributes to the extant literature on motive for foreign remittance by providing evidence of the dynamic nature of the motive for foreign remittance. Moreover, it helps policymakers to design foreign remittance policy to ensure the sustainable inflow of foreign remittance, taking the importance of economic development and political stability into consideration.

The rest of the paper is structured as follows. Section 2 briefly reviews the pertinent literature, Section 3 provides information about the data, methods used in analysis, and results of the statistical analysis; this is followed by the summary and conclusion of the study in Section 4 .

\section{LITERATURE REVIEW}

\section{Motive for Foreign Remittance}

The motive for foreign remittance is one of the key aspects of remittance-related literature. Review of literature shows no consensus on motive for foreign remittance, as studies support altruism, self-interest,or a mix of both.

Agarawal and Horowitz (2002) supported the altruistic motive; that is, remittance is more focused on migrants' aspirations to fulfil the needs and wants of family members back at home. The authors tested altruistic versus self-interest motives using the Guyana Household Income and Expenditure Survey and Living Standard Measurement Study. According to their study, the inflow of remittance to Guyana is motivated by altruism and has a significant positive association with the number of migrants in a family. The finding by Agarawal and Horowitz has been reinforced by the findings of Bouoiyour and Miftah (2015), who also supported the altru- 
istic motive for remittance in Guyana. In contrast, Czaika and Spray (2013) supported mix of altruism and self-interest.

Briereet al. (2002) classify motive for remittances into two categories: insurance and investment. They hypothesized that whether the motive is insurance or investment depends on the destination (internal or international) and the gender of migrants. They tested this using household survey data from the Dominican Republic. According to Lucas and Stark's (1985) classification of remittance motive. The identified insurance motive is mostly covered under the altruistic motive, while the investment motive is covered under selfinterest. The above findings show that motive for remittance could be different from country to country and depends on factors such as the number of migrants in a family, the gender of the migrants and the destination.

The previously mentioned studies are based on household survey data and on a single point in time; for example, Agarawal and Horowitz's study is only based on data from 1992 and 1993. Going beyond the micro-economic studies, other researchers have focused on macro-economic analysis on the motive for remittance and showed how it varies depending on economic and financial conditions.

For instance, Lueth and Ruiz Arranz (2007) examined whether remittance was a hedge against macro-economic shocks in Sri Lanka. Their study found that inflow of remittance to Sri Lanka is pro-cyclical; that is, remittance increases with the acceleration of economic performance, showing a positive association (proxy with GDP in Sri Lanka) and vice versa. Thus, Lueth and Ruiz Arranz (2007) confronted the verdicts of Rapoport and Docquier (2006), who claimed that remittance is largely if not solely based on altruism. Nonetheless, their study did not provide any conclusions on the Sri Lankan context, and suggested the importance of further analysis.

Lueth and Ruiz Arranz's (2007) study was based on quarterly data for Sri Lanka from 1996 to 2004 and did not capture the period preceding through the 1980sor beyond 2004 . Therefore, a study which covers a wider period might help resolve the issue of what motive is dominant in developing countries. Fonchamnyo (2012) conducted a study based on Sub-Saharan Africa to examine the motive for remittance. The study was based on unbalanced panel data of 36 countries in the period1980-2009. According to this study, the inflow of remittance to Sub-Saharan Africa supports the altruistic motive.

In summary, there is no consensus on migrants' motives to remit to their home countries. Researchers support altruism (Agarawal and Horowitz, 2002), self-interest (Briere et al., 2002) as well as the mix of both (Czaika and Spray, 2013). Non-availability of compromise on the motive behind remittance weakens the generalising of onecountry's findings to another.

Furthermore, categorizing the motive for remittance as altruistic, self-interest or a mix of both varies by the time period of the study. For example, Alleyne (2006) considered 19822002 and found that remittance to Jamaica was motivated by altruism whereas Henry et al. (2009) examined the same country for 1995-2008 and concluded that remittance to
Jamaica was motivated by a mix of altruism and self-interest. This shows the probable dynamic nature of the motive for remittance of a country over time. Nonetheless, based on two different studies, one cannot make a conclusion as the method of data collection and analysis differs from one study to the next.

This brings up a question of whether we can hold the same notion of motive for remittance for a country over time or whether it could change over the period. This is one of the untouched areas of research in the motive for remittance; that is, the dynamic nature of the motive for foreign remittance (altruism to self-interest or vice versa) and the mix of motive (mix of altruistic and self-interest) are two different aspects. To the best of our knowledge, analysis of the dynamic nature of motive for foreign remittance has received little attention in the literature. To test the hypothesis that the motive for foreign remittance is dynamic over time, this study first identifies the determinants of foreign remittance and then develops an econometric model on both long- and short-run determinants.

\section{Determinants of Foreign Remittance}

Foreign remittance is a major source of foreign exchange to developing countries in the world. It is determined by the micro- and macro-economic conditions (Adams, 2009) of both the home and the host countries (Swamy, 1981; ElSakka and McNabb, 1999),as well as social and political factors(Arun and Ulku, 2011). The literature review identified the following economic variables as determinants of foreign remittance. Firstly, foreign remittance is measured as a ratio of GDP of the country.

Rem $=f$ (Per Capita GPD Home, Political Risk Home, Lending Interest Rate Home, Deposit Interest Rate Home, Inflation Home, Per Capita GDP Host, Oil Rent Host)

\section{Per Capita GDP Home}

This measures the home country level of economic performance (Lucas and Stark, 1985; Coulibaly, 2015;El Sakka and McNabb, 1999). The role of per capita GDP as a determinant of foreign remittance varies depending on the motive for remittance (Alleyne, 2006). For instance, altruism generally embeds the need of the household back at home in the total utility of migrants. Low per capita GDP in the home country signals the necessity of migrants' support for household needs. Thus, an inverse relationship between per capita GDP and remittance is expected. The trend of increasing remittance mainly for consumption (Rapoport and Docquier, 2006) when per capita GDP is low shows the role of remittance as "insurance" against economic shocks (Lueth and Ruiz Arranz, 2007).

In contrast, a higher level of per capita GDP diverts migrants' remittance from household consumption to saving and investment. Hence, the positive relationship between remittance and per capita GDP reflects the self-interest motive; that is, sending money mainly for savings and investment (McCracken et al., 2017). The above relationships are on par with the analysis of Giuliano and Ruiz-Arranz (2009), who examined the pro-cyclical and counter-cyclical nature of remittance. 


\section{Political Risk}

Political and/or government instability is often a major issue in developing countries. According to the "Theory of Migration" (Ravenstein, 1889) political repression or the risk is considered as a push factor of migration. It stimulate people to migrate to other countries and encourage them for permanent settlement in politically as well as economically stable countries. Nonetheless, how this influences temporary migration and remittance from those temporary migration has rarely been examined in the literature. Moreover, the available few studies used per capita GDP as a proxy for political risk measures which is not a sound proxy to a great extent (e.g. Sandra, 2003).

This study uses political risk indicators from the International Country Risk Guide (ICRG) of PRS Group, which is recognized as the comprehensive measure of political stability of a country (Howell, 2011). Table 1 shows the 12 categories of political risk in the ICRG. According to the ICRG analysis, higher index indicates low risk and vice versa. We used factor analysis to derive the three political risk components shown in Figure 1: namely, political stability, accountability, and socioeconomic status. According to the factor analysis, government stability, investment profile, internal conflicts, external conflicts, law and order, and ethnic tension fall under government stability, whereas corruption, religion in politics and democratic accountability come under accountability. Socioeconomic status is the only risk component of the 12 which falls under the third category of political risk. ${ }^{2}$

Table 1. Political Risk Components.

\begin{tabular}{|c|c|}
\hline Component & Definition \\
\hline Government Stability & $\begin{array}{l}\text { The government capability to carry out } \\
\text { acknowledged programs and the ability to } \\
\text { stay in office. This covers government } \\
\text { unity, legislative strength, and popular } \\
\text { support. }\end{array}$ \\
\hline Socioeconomic Conditions & $\begin{array}{c}\text { The socioeconomic pressure at work. This } \\
\text { covers unemployment, consumer confi- } \\
\text { dence and poverty. }\end{array}$ \\
\hline Investment Profile & $\begin{array}{l}\text { The investment-related risk factors, which } \\
\text { do not cover the political, economic, and } \\
\text { financial risk components. This includes } \\
\text { contract viability/expropriation, profit } \\
\text { repatriation and payment delays. }\end{array}$ \\
\hline Internal Conflict & $\begin{array}{l}\text { Actual and probable influence of political } \\
\text { violence on governance. It includes civil } \\
\text { warand coup threats, terrorismand politi- } \\
\text { cal violence, and civil disorder. }\end{array}$ \\
\hline External Conflict & $\begin{array}{l}\text { War, cross-border conflicts, and foreign } \\
\text { pressures. It covers non-violent as well as } \\
\text { violent pressures. }\end{array}$ \\
\hline Corruption & $\begin{array}{l}\text { The severity of corruption within the } \\
\text { country's political system. }\end{array}$ \\
\hline
\end{tabular}

${ }^{2}$ Bureaucracy quality has been removed due to the non-variability of the data.

\begin{tabular}{|c|c|}
\hline Military in Politics & Involvement of military forces in politics. \\
\hline Religious Tensions & $\begin{array}{l}\text { The extent to which a religious group in a } \\
\text { country dominates political and govern- } \\
\text { ment decisions by replacing civil law with } \\
\text { religious law. }\end{array}$ \\
\hline Law and Order & $\begin{array}{l}\text { Law - the strength and impartiality of a } \\
\text { country's legal system. } \\
\text { Order - popular observance of the law. }\end{array}$ \\
\hline Ethnic Tensions & $\begin{array}{l}\text { The tension attributable to the diversity of } \\
\text { races, nationalities, and languages. }\end{array}$ \\
\hline Democratic Accountability & Government responsiveness to the people. \\
\hline Bureaucracy Quality & $\begin{array}{l}\text { The strength and quality of government } \\
\text { policies and the extent to which they } \\
\text { would change with achange of governing } \\
\text { political party. }\end{array}$ \\
\hline
\end{tabular}

Source: International Country Risk Guide, 2011

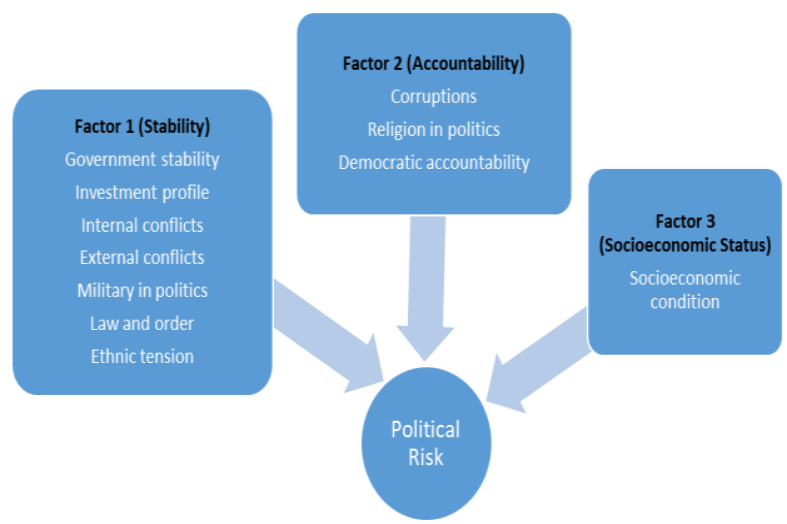

Fig. (1). Political Risk Categorisation.

\section{Interest Rates}

Various forms of interest rates, such as the deposit rate (Alper and Neyapti, 2006) and the differential between home and host country interest rate (Swamy, 1981; Coulibaly, 2009; Nnyazi, 2016) are common and demonstrate mixed results. For instant, Coulibaly (2009), El-Sakka and McNabb (1999) and Fonchamnyo (2012) found that the differential between home and host country interest rate is significant and positive in determining the level of remittance. Hence, as explained by Nnyanzi (2016), it indicates the existence of an investment motive for remittance. However, in contrast to the above positive association, Azizi (2018) concluded that the interest rate is not statistically significant as a determinant of remittance. The availability of mixed results motivated the authors herein to reassess the interest rate as a determinant of foreign remittance in this study. Hence, instead of the differential between home and host country interest rate, this study uses lending 3 and deposit4 interest rates to exam-

${ }^{3}$ Lending rate is the bank rate that usually meets the short- and medium-term financing needs of the private sector. 
ine whether interest rate is a key determinant of foreign remittance.

\section{Level of Inflation}

The level of inflation in the home country (Elbadawi and Mundial, 1992; El-Sakka and McNabb, 1999)signals the economic stability of the country and thus acts as a proxy for the level of risk (Elbadawi and Mundial, 1992). Higher inflation discourages self-interest, as it erodes the value of foreign currency. On the other hand, it encourages altruistic migrants due to the increased consumption expenditure, and people at home seeking more support from migrants abroad (El-Sakka and McNabb, 1999). This study uses the consumer price index (CPI) in Sri Lanka, which reflects changes in the cost to the average consumer of acquiring a basket of goods and services.

\section{Per Capita GDP ksA}

Migration to oil-exporting Gulf Corporation Council (GCC) countries is a key feature of most remittance-dependent countries in Asia including Sri Lanka. Despite recent trends in migration to other countries such as South Korea and Maldives, oil-exporting countries are the most attractive destinations for Sri Lankan migrants. Migration to oil-exporting countries has existed for the last six decades and intensified since the 1970s. In 2016, $86 \%$ of Sri Lankan migrants went to oil-exporting countries, compared to $14 \%$ to the rest of the world. In 2017, $90 \%$ of total Sri Lankan migrants live in oilexporting Middle Eastern countries and their total remittance was LKR 565,422 million, which was 52\% of all remittance (Sri Lanka Bureau of Foreign Employment, 2017). However, non-availability of data for the 1980s for all of these oilexporting countries constrained the calculation of a composite index (weighted average per capita GDP). Therefore, per capita GDP in the Kingdom of Saudi Arabia (KSA) was used to proxy the GCC countries, as it has been the main destination for Sri Lankan migrants over the last three decades. According to the Sri Lanka Bureau of Foreign Employment (2017), more than one-quarter of Sri Lankan migrants head to $\mathrm{KSA}$ (in 2016 , they represented $26 \%$ of total migration).

\section{Oil Rent}

The main income of GCC countries is from oil exports. The price of oil fluctuates greatly, and this could be a factor which limits the demand for migrants, their income and thereforeremittance. Lueth and Ruiz Arranz (2007) propose oil price as a good proxy for host country economic activities, showing that a $\$ 2.80$ per barrel increase in oil price would increase remittance by $\$ 14$ million $(1 \%)$ in the first year and another $\$ 3$ million in subsequent years. This study goes a step furtherby introducing oil rent, which is more realistic than oil price. Oil rent is the difference between the value of crude oil production at world prices and the total cost of production; this is the first study to introduce this variable into research.

${ }^{4}$ Deposit interest rate is the rate paid by commercial or similar banks for demand, time or savings deposits.

\section{DATA AND DATA ANALYSIS}

This study obtained time series data for 1984-2016 from the Balance of Payments statistics yearbook of the International Monetary Fund, International Financial Statistics of World Bank and the ICRG.

First, the analysis commenced with bivariate correlation to avoid the multicolliniarity problem. Based on the correlation results, ${ }^{5}$ PCGDP Home, Oil Rent KSA, and Lending Interest Rate (IntLend) was added to the model while removing the rest. The pre-test of correlation aids robust statistical analysis; otherwise, the model would be biased, being comprised ofmacro-economic variables which are highly correlated in nature.

The time series plots of the selected variables exhibit trends of the variables. As shown in Figure 2, government stability shows an upward trend with a negative intercept that portrays the overall political stability of the country, moving from instability to stability. Accountability shows a downward trend with a positive intercept reflecting weakening accountability over the period. The socioeconomic status has a positive intercept with no clear trend in the data. The lending interest rate has a relatively declining trend, whereas the rest of the three variables - Per Capita GDP Home, Per Capita GDP KSA and Oil Rent KSA- demonstrate an upward trend.

Following the time series plots in Figure 2, an augmented Dicky-Fuller (ADF) test was used to examine the stationarity of the data (Dickey and Fuller 1976; 1981). It revealed that except for accountability and socioeconomic status, all the other variables are I (1). The PP test (Phillips and Perron, 1988) confirmed the results of the ADFtest except for accountability.

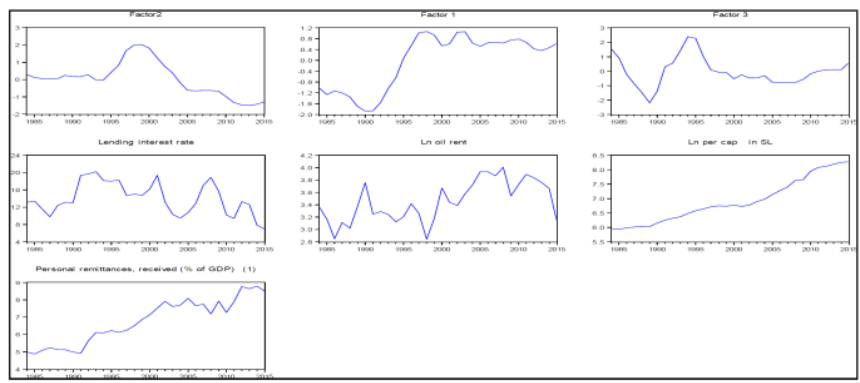

Fig. (2). Time Series Plots.

Note: Factor 1- Government Stability, Factor 2- Accountability, Factor 3- Socioeconomic Status

The availability of mixed I (0) and I (1) confirmed the use of the auto regressive distributed lag (ARDL) model of Pesaran et al. (2001), which is shown in Equation 1. The number of lag selection was based on Akaike Information Criterion (AIC) and the same conclusion was derived based on both Schwarz Information Criterion (SIC) and Hannan-Quinn Information Criterion (HQ) . The number of lags is compatible with Pesaranet al. (1999), who suggested a maximum of two lags for annual time series data.

\footnotetext{
${ }^{5}$ Annexure 1.
} 
Auto-Regressive Distributed Lag Model

$$
\begin{aligned}
& \Delta \text { Rem }=a_{0}+\sum_{j=1}^{2} \emptyset_{j} \Delta \text { Rem }_{t-j}+\sum_{j=1}^{2} \theta_{j} \Delta \text { PCGDP }_{t-j}+\sum_{j=1}^{2} \lambda_{j} \Delta \text { Oil }_{t-j} \\
& +\sum_{j=1}^{2} \varphi_{j} \text { Intlend }_{t-j}+\sum_{j=1}^{2} \vartheta_{j} \Delta \text { Stability }_{t-j}+\sum_{j=0}^{2} \theta_{j} \text { Accountability }_{t-j}+ \\
& \sum_{j=0}^{2} \mathrm{t}_{j} \text { Socioeconomic }_{t-j}+\delta_{1} \text { Rem }_{t-1}+\delta_{2} \text { PCSL }_{t-1}+\delta_{3} \text { Oil }_{t-1} \\
& +\delta_{4} \text { Intlend }_{t-1}+\delta_{5} \text { Stability }_{t-1}+e_{t}
\end{aligned}
$$

Where Rem is remittance, PCGDP and Oil are Per Capita GDP Home and Oil Rent Host respectively. Intlend is the lending interest rate and Stability, Accountability and Socioeconomic are the political risk components.

The Breusch-Godfrey Serial Correlation Lagrange Multiplier test assessed the null hypothesis of no serial correlation against the alternative hypothesis of serial correlation in the model. The Prob Chi-Square of 0.0582, which is higher than $5 \%$ level, supports the rejection of the null hypothesis, concluding no serial correlation in the model. Along with the serial correlation, the stability of the model is confirmed by KUSUM test.

The above preliminary analysis validated the test of cointegration in the model. To begin with bound testing, the study then tested for the null of no cointegration among variables $(\mathrm{H} 0: \delta 1=\delta 2=\delta 3=\delta 4=\delta 5=0)$ against the alternative of cointegration or the existence of long-run association $n(\mathrm{H} 1: \delta 1 \neq$ $\delta 2 \neq \delta 3 \neq \delta 4 \neq \delta 5 \neq 0$ ).

Table 2. Wald Test.

\begin{tabular}{|c|c|c|}
\hline Test Statistic & Value & Probability \\
\hline F-statistic & 5.399483 & 0.0114 \\
\hline Chi-square & 37.79638 & 0.0000 \\
\hline
\end{tabular}

Given the small sample size, this study used Narayan's(2004) critical value to assess the cointegration based on the Wald test results in Table 2 . The F-statistic, which is higher than the upper bound critical value, leads to the rejection of above the null hypothesis, concluding the cointegration in the model. Thus, we estimated the long-run model in Equation 2 and the results are shown in Table $\mathbf{3}$.

Long-Run Model

$$
\begin{aligned}
& \text { Rem }_{t}=0.3629+0.7970 \text { PCGDP } \\
& +-i+0.2593 \text { Oil }_{t-i} \\
& +0.0013 \text { Intlend }_{t-i}+0.5944 \text { Stability }_{t-i} \\
& -0.1588 \text { Accountability }_{t-i}-0.0422 \text { Socioeconomic }_{t-i}+e_{t}
\end{aligned}
$$

Table 3. Long-Run Elasticity, 1984-2016.

\begin{tabular}{|c|c|}
\hline Variable & Elasticity \\
\hline PCGDP & $0.796959^{*}$ \\
\hline Oil Rent $_{\text {Host }}$ & 0.259324 \\
\hline
\end{tabular}

\begin{tabular}{|c|c|}
\hline Lending Interest Rate $_{\text {Home }}$ & 0.001291 \\
\hline Government Stability & $0.594434^{* *}$ \\
\hline Accountability & -0.158835 \\
\hline Socioeconomic Status & -0.042239 \\
\hline
\end{tabular}

Note: $*$ Sig. at $5 \%$ level; ** Sig. at $1 \%$ level

The long-run coefficient for per capita GDP in the home country is positive and significant at $5 \%$, which is observed in Table 3. This is on par with the findings of Gubert (2002), Catrinescu et al. (2006) and Arun and Ulku (2011). The significant positive coefficient supports the self-interest motive behind remittance. As stated in Arun and Ulku (2011), selfinterest for remittance toSri Lanka could be justifiable given South Asian migrants' desires to acquire land and save money for future endeavours. Importantly, the identified remittance - per capita GDP nexus answers the unsolved notion in Lueth and Ruiz Arranz (2007), who questioned the altruistic motive for remittance where inflow of foreign remittance is pro-cyclical in Sri Lanka.

According to the long-run elasticity, government stability is a positive and significant determinant on the inflow of foreign remittance. This is a composite index of government stability, investment profile, internal conflicts, external conflicts, the military in politics, law and order and ethnic tension. The increase in the index indicates the reduction of risk. Thus, a focus on enhancing government stability could increase the inflow of remittance. This further supports the identified self-interest motive, as political or government stability is one of the key considerations for investment. This shows that migrants tend to remit more with the increase of stability of the government. This is on par with the finding of Catrinescu et al. (2006), who highlighted the importance of higher quality political policies to enhance the development impact of sustainable remittance. According to the systematic theory of migration, political repression is a push factor hence political stability in home country should discourage the migration and remittance should be reduced. Our analysis, shows the need of examining the systematic theory of migration by specifically focusing on permanent and temporary migrations separately.

Another aim wasto find out whether GCC countries' income and oil price fluctuations influence the inflow of foreign remittance to Sri Lanka. However, no evidence to support this was found inthe long-run model. As shown in the time series plots in Fig. (2), both variables show an upward trend in the longrun. Besides the annual time series, monthly or quarterly time series data may help further investigation of these determinants. None of the other variables were significant determinants in the long run. However, they cannot be ignored, as they might be significant in the shortrun.

The error correction model in Equation 3 attempts to assess the speed of adjustment or speed of convergence to equilibrium (Duasa, 2007) and to identify short-run determinants.

Short-Run Dynamic Model (Error Correction Model) 


$$
\begin{aligned}
& \Delta \operatorname{Rem}_{t}=a_{0}+\sum_{i=1}^{2} \emptyset_{i} \Delta \text { Rem }_{t-i}+\sum_{i=1}^{2} \theta_{j} \Delta P C G D P_{t-i} \\
& +\sum_{i=1}^{2} \lambda_{j} \Delta \text { Oil }_{t-i}+\sum_{i=1}^{2} \varphi_{j} \Delta \text { Intlend }_{t-i}+\sum_{i=1}^{2} \vartheta_{j} \Delta \text { Stability }_{t-i} \\
& +\sum_{i=0}^{2} \theta_{j} \text { Accountability }_{t-i}+\sum_{i=0}^{2} \mathrm{t}_{j} \text { Socioeconomic }_{t-i} \\
& +\psi \text { ECM }_{t-1}+e_{t}
\end{aligned}
$$

As shown in Table 4, the negative and significant lagged error correction term confirmed the validity of the model. The model has an $89 \%$ speed of adjustment or rate of convergence to equilibrium. The results further reveal the possibility of at least unidirectional causality. In the shortrun, accountability and socioeconomic condition are significant determinants of remittance, both significant at the $5 \%$ level.

Table 4. Error Correction Model, 1984-2016.

\begin{tabular}{|c|c|c|c|c|}
\hline Variable & Coefficient & Std Error & $\mathrm{t}$-Statistic & Prob. \\
\hline $\mathrm{C}$ & 0.273079 & 0.123037 & 2.219484 & 0.0371 \\
\hline $\mathrm{d}($ REM(-2)) & 0.248953 & 0.173072 & 1.438437 & 0.1644 \\
\hline $\mathrm{d}(\mathrm{PCGDP}(-1))$ & -2.389990 & 1.420222 & -1.682828 & 0.1065 \\
\hline $\begin{array}{c}\mathrm{d}(\text { Lending Interest } \\
\text { Rate(-1) })\end{array}$ & 0.022255 & 0.021292 & 1.045261 & 0.3073 \\
\hline $\mathrm{d}($ Accountability(-1)) & -0.598442 & 0.266432 & -2.246132 & 0.0351 \\
\hline $\begin{array}{c}\mathrm{d}(\text { Socioeconomic } \\
\text { Status(-2)) }\end{array}$ & 0.236279 & 0.113326 & 2.084947 & 0.0489 \\
\hline ECT(-1) & -0.893851 & 0.250055 & -3.574624 & 0.0017 \\
\hline
\end{tabular}

Up to this point, neither the long-run nor the short-run model helps to identify whether the motive for remittance is static or dynamic over a period. To examine this, the study then considered recursive estimation (Song and Witt, 2000) on only the significant variables in the above long-run model.

To initiate the analysis, we applied the OLS regression using significant variables in the above long-run model. The coefficients of PCGDP and Government Stabilitywere1.0897 and 0.4519 respectively, significant at the $1 \%$ level. The significant positive coefficients are consistent with the selfinterest/investment motive (McCracken et al., 2017). The OLS estimate assumes that these coefficients are constant over the sample period. If this assumption is valid, it proves that motive to remit is constant (static); that is, the selfinterest/investment motive is valid over the sample period.

The recursive OLS estimates started with a subsample selection based on the least square break method, which satisfied the conditionst $=1,2 \ldots n$, where $n \geq k$. This means that the number of observations in the sample should exceed the number of parameters to estimate.
The least square break method proposed six subsamples; the first sample, which ends in 1991, was chosen for the analysis. The number of observations was extended by one at a time and the model re-estimated until the last observation of the sample.

The results of the recursive estimates are shown in Figure 3 and 4. As illustrated in Figure 3, the coefficient of PCGDP in the initial model was- 0.8688 , which is consistent with the altruistic motive. However, since 1992 the coefficients have changed significantly and started to become positive over the estimation period. For example, when the initial model was extended by $\mathrm{n}+1$, the coefficient changed from negative 0.8688 to positive 1.5539 . This means the motive for remittance was altruistic prior to 1992 , and changed to selfinterest thereafter. The value of the positive coefficient changed over the sample period. Nonetheless, it then stayed positive continuously since 1992, showing that the selfinterest motive dominates over altruism.

The identified dynamic nature of motive for foreign remittance might be partially due to two main government policies which directly affected the main migrants in Sri Lanka. Firstly, it may be due to the initiation of subsidiary program for poor people in the country6. Because, poverty in Sri Lanka has often forced people to migrate and remittance helped families to fulfil their basic needs and come out of extreme poverty which is explained in altruism. Given the support from the government migrants could focus more on savings and investment. This might help to justify the shift of motive for foreign remittance from altruism to selfinterest, which happened after two years the initiation of Janasaviya.

Further, the coefficient of PCGDP shows an upward trend from 1992 to 2006 and declines gradually thereafter until 2011. During 2010-2012, the coefficient values are less than one and improved afterwards. To some extent, this might account for government policy on female migration. The decision of the government to encourage male migrants while strengthening rules on female migrants changed the ratio of male: female migrants (SLBFE, 2016). As such, female migration has declined since 2010. As a percentage, it declined from $52 \%$ in 2009 to $49 \%$ in 2010; in 2017, the recorded male and female migration was $66 \%$ and $34 \%$ respectively.

However, the remittance of female migrants was the main remittance inflow in Sri Lanka. As stated in Briere et al. (2002), female migrants' motive for remittance is insurance or altruistic in nature, compared to males who are motivated more by self-interest. Thus, the change in male: female migration ratio is a possible reason behind the identified move from altruism to self-interest. Moreover, changes in skill composition, with an upsurge in skilled and semi-skilled migration but a decline in housemaid migration (SLBFE, 2017), might also be a cause for the identified shift of the motive for foreign remittance. Skilled and semi-skilled mi-

"Sri Lankan government introduced "Janasaviya" a subsidiary program for poor people to assist them to overcome poverty in October 1989. This program mainly targeted to help them fulfil their basic needs and formed selfhelp groups to strengthen their financial inclusion and mutual support. 
grants employed in foreign countries do not necessarily have more chances to get back to the labour force in their home country upon their return. Thus, many of them might focus on saving money to start up their own business, which comes under the self-interest motive. However, housemaids' intentions to migrate are probably mostly to do with poverty; this is altruistic, as discussed in the literature.

We used two dummy variables to check the validity of the above justification on the reasons for the move of motive for remittance from altruistic to self-interest; however, they were not statistically significant due to the small sample size.

The recursive estimates of government stability were positive throughout the sample period. This variable recorded the lowest coefficient before 1991, where altruism dominates the foreign remittance to Sri Lanka. According to the analysis, a low level of government stability is associated with altruism whereas a high level of government stability supports selfinterest. These findings are valuable for policymakers, as policies should be compatible with the motive to remit.

\section{Recursive Estimates of Coefficients - Per Capita GDP}

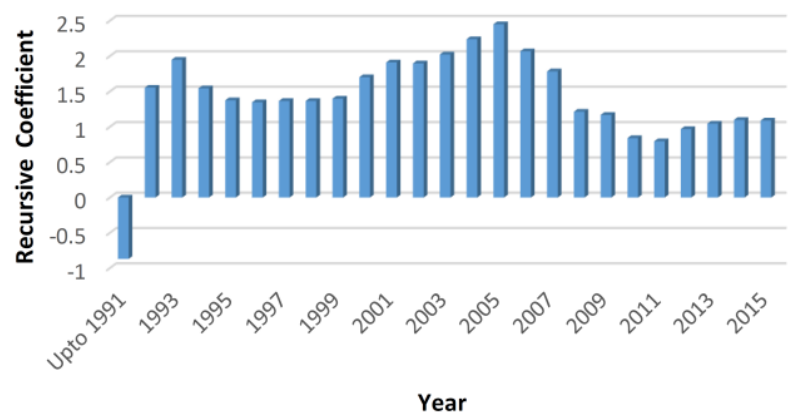

Fig. (3). Recursive Estimates of Coefficients - Per Capita GDP

Recursive Estimates of Coefficients - Government Stability

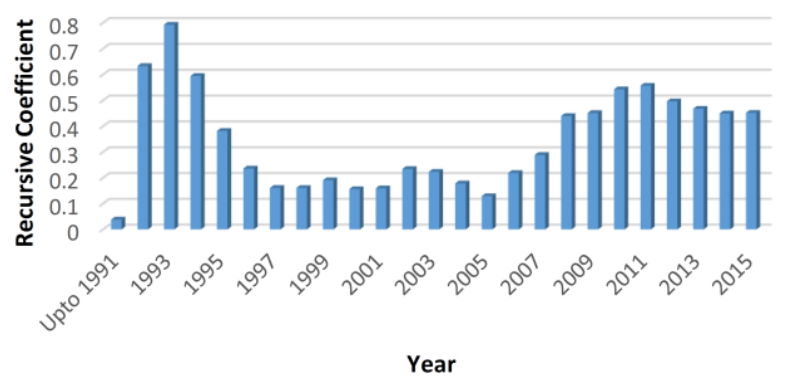

Fig. (4). Recursive Estimates of Coefficients - Government Stability

\section{CONCLUSION AND POLICY IMPLICATIONS}

This paper has made the first attempt to study the dynamic nature of the motive for remittance over time in a macroeconomic framework. The study found that migrants' motive for remittance is not static but varies according to changes in economic, political and social policy conditions. This is evident with the change in the recursive estimate coefficient of per capita GDP from negative to positive, which occurred in the 1991-1992 period. This means that before 1992, per cap- ita GDP and inflow of foreign remittance were countercyclical, but then pro-cyclical afterwards. Further, this study also found per capita GDP and political stability as key determinants of foreign remittance in the long run, while accountability and socioeconomic conditions were important in the short run.

According to the findings, governments need to focus on increasing government stability. This includes the reduction of risk related to government stability, investment profile, internal conflicts, external conflicts, law and order, and ethnic tension, which comes under the broader category of stability. Government stability ensures favourable conditions for investors and the identified investment motive is compatible with the proposed policy suggestions. This further suggest that "systematic theory of migration"

Further, foreign remittance to Sri Lanka in particular mainly depends on the per capita GDP of the home country, and if remittance is insufficient for the consumption needs and utility of households in the home country, migrants will have to change their motive from self-interest to altruistic. Thus, continuous attention to improve GDP in the home country is vital, as remittance motivated by self-interest has a higher development impact than altruistically motivated remittance.

This is the first study to examine the dynamic nature of motive for remittance, and therefore fills a gap in the literature. Further, by uncovering key determinants and the behavior of motive for remittance, this study has the potential to assist policymakers to develop more effective policies to ensure the sustainable inflow of remittance. The findings could be extended to various countries and across-country level data to improve the validity of the so-called dynamic nature of foreign remittance and the identified remittance-government stability nexus.

\section{CONFLICT OF INTEREST STATEMENT}

The authors declare that they have no conflict of interest.

\section{ABBREVIATIONS}

$\begin{array}{lll}\text { ARDL } & = & \text { Auto Regressive Distributed Lag model } \\ \text { GCC } & = & \text { Gulf Corporation Council Countries } \\ \text { GDP }= & \text { Gross Domestic Product } \\ \text { ICRG }= & \text { International Country Risk Guide } \\ \text { KSA }= & \text { Kingdom of Saudi Arabia } \\ \text { PCGDP }= & \text { PerCapita Gross Domestic Product }\end{array}$

ANNEXURE

Correlation Analysis

\begin{tabular}{|c|c|c|c|c|c|c|}
\hline & $\begin{array}{c}\text { Lending } \\
\text { Interest } \\
\text { Rate }\end{array}$ & $\begin{array}{c}\text { Deposit } \\
\text { Interest } \\
\text { Rate }\end{array}$ & $\begin{array}{c}\text { Price } \\
\text { Level }\end{array}$ & $\begin{array}{c}\text { PCGDP } \\
\text { (SL) }\end{array}$ & $\begin{array}{c}\text { PCGDP } \\
\text { (KSA) }\end{array}$ & $\begin{array}{c}\text { Oil } \\
\text { Rent }\end{array}$ \\
\hline $\begin{array}{c}\text { Lending } \\
\text { Interest Rate }\end{array}$ & 1 & $.531^{* *}$ & - & $-.482^{* *}$ & $-.391^{*}$ & -.161 \\
\hline
\end{tabular}




\begin{tabular}{|c|c|c|c|c|c|c|}
\hline $\begin{array}{c}\text { Deposit Inter- } \\
\text { est Rate }\end{array}$ & $.531^{* *}$ & 1 & $\begin{array}{c}- \\
.627^{* *}\end{array}$ & $-.550^{* *}$ & $-.548^{* *}$ & $\begin{array}{c}- \\
.384^{*}\end{array}$ \\
\hline Price Level & $-.435^{*}$ & $-.627^{* *}$ & 1 & $.976^{* *}$ & $.970^{* *}$ & $.577^{* *}$ \\
\hline PCGDP(SL) & $-.482^{* *}$ & $-.550^{* *}$ & $.976^{* *}$ & 1 & $.963^{* *}$ & $.472^{* *}$ \\
\hline PCGDP(KSA) & $-.391^{*}$ & $-.548^{* *}$ & $.970^{* *}$ & $.963^{* *}$ & 1 & $.657^{* *}$ \\
\hline Oil Rent & -.161 & $-.384^{*}$ & $.577^{* *}$ & $.472^{* *}$ & $.657^{* *}$ & 1 \\
\hline
\end{tabular}

Note: * Sig. at $5 \%$ level; $* *$ Sig. at $1 \%$ level.

\section{REFERENCES}

Abdin, Z. U., and M. B. Erdal."Remittance-sending among Pakistani taxidrivers in Barcelona and Oslo: Implications of migrationtrajectories and the protracted electricity crisis in Pakistan." Migration and Development 5, no. 3 (2016): 378-393.

Adams Jr, Richard H. "The determinants of international remittances in developing countries." World Development 37, no. 1 (2009): 93103.

Agarwal, Reena, and Andrew W. Horowitz."Are international remittances altruism or insurance? Evidence from Guyana using multiplemigrant households." World development 30, no. 11 (2002): 20332044.

Alleyne, Dillon. "Motivations to Remit in CARICOM: A GMM approach." Social and Economic Studies (2006): 69-87.

Alper, Ahmet Murat, and BilinNeyapti."Determinants of workers' remittances: Turkish evidence from high-frequency data." Eastern European Economics 44, no. 5 (2006): 91-100.

Arun, Thankom, and HulyaUlku."Determinants of remittances: The case of the South Asian community in Manchester." Journal of Development Studies 47, no. 6 (2011): 894-912.

Azizi, S. "Why Do Migrants Remit?”World Economy 1(24), 2018.

De la Briere, Benedicte, Elisabeth Sadoulet, Alain De Janvry, and Sylvie Lambert."The roles of destination, gender, and household composition in explaining remittances: an analysis for the Dominican Sierra." Journal of Development Economics 68, no. 2 (2002): 309-328.

Catrinescu, Natalia, Miguel Leon-Ledesma, MatloobPiracha, and Bryce Quillin."Remittances, institutions, and economic growth." World Development 37, no. 1 (2009): 81-92.

Coulibaly, Dramane. "Remittances and financial development in SubSaharan African countries: A system approach." Economic Modelling 45 (2015): 249-258.

Coulibaly, Dramane. "Macroeconomic determinants of migrants' remittances: New evidence from a panel VAR." (2009).

Czaika, Mathias, and John Spray."Drivers and dynamics of internal and international remittances." The Journal of Development Studies 49, no. 10 (2013): 1299-1315.

Dickey, David A., and Wayne A. Fuller."Distribution of the estimators for autoregressive time series with a unit root." Journal of the American statistical association 74, no. 366a (1979): 427-431.

Dickey, David A., and Wayne A. Fuller."Likelihood ratio statistics for autoregressive time series with a unit root." Econometrica: Journal of the Econometric Society (1981): 1057-1072.

Duasa, Jarita. "Determinants of Malaysian trade balance: An ARDL bound testing approach." Global Economic Review 36, no. 1 (2007): 89102.

El-Sakka, Mohammed IT, and Robert McNabb."The macroeconomic determinants of emigrant remittances." World Development 27, no. 8 (1999): 1493-1502.
Elbadawi, Ibrahim, and Banco Mundial. Macroeconomic management and the black market for foreign exchange in Sudan. Washington, $D C$ : World Bank, 1992.

Fonchamnyo, Dobdinga Cletus. "The Altruistic Motive of Remittances A Panel Data Analysis of Economies in Sub Saharan Africa", International Journal of Economics and Finance, 4(10),2012

Giuliano, P, and M. Ruiz-Arranz, "Remittances, financial development, and growth."Journal of Development Economics, 90(1). 2009, 144152.

Gubert, Flore. "Do migrants insure those who stay behind? Evidence from the Kayes area (Western Mali)." Oxford Development Studies 30, no. 3 (2002): 267-287.

Henry, Chandar, Jermaine Moulton, and Jermaine Ricketts. "Motives for sending Remittances to Jamaica: An application of the BPM6 definition of Remittances." Bank of Jamaica(2009).

Howell, Llewellyn D. "International country risk guide methodology." East Syracuse, NY: PRS Group (2011).

Lucas, Robert EB, and Oded Stark. "Motivations to remit: Evidence from Botswana." Journal of political Economy 93, no. 5 (1985): 901918.

Lueth, Erik, and Marta Ruiz-Arranz. Are workers' remittances a hedge against macroeconomic shocks? The case of Sri Lanka. International Monetary Fund, 2007.

McCracken, Scott, Carlyn Ramlogan-Dobson, and Marie M. Stack. "A gravity model of remittance determinants: evidence from Latin America and the Caribbean." Regional Studies 51, no. 5 (2017): 737-749.

Nnyanzi, John Bosco. "What drives international remittances to Africa: Altruism, self-interest or the institutional environment?" African Journal of Economic and Management Studies 7, no. 3 (2016): 397-418.

Narayan, Paresh. Reformulating critical values for the bounds F-statistics approach to cointegration: an application to the tourism demand model for Fiji. Vol. 2, no. 04. Australia: Monash University, 2004.

Phillips, Peter CB, and Pierre Perron. "Testing for a unit root in time series regression." Biometrika 75, no. 2 (1988): 335-346.

Perron, Pierre. "Trends and random walks in macroeconomic time series: Further evidence from a new approach." Journal of economic dynamics and control 12, no. 2-3 (1988): 297-332.

Pesaran, M. Hashem, Yongcheol Shin, and Ron P. Smith. "Pooled mean group estimation of dynamic heterogeneous panels." Journal of the American Statistical Association 94, no. 446 (1999): 621-634.

Pesaran, M. Hashem, Yongcheol Shin, and Richard J. Smith. "Bounds testing approaches to the analysis of level relationships." Journal of applied econometrics 16, no. 3 (2001): 289-326.

Rapoport, Hillel, and Frédéric Docquier. "The economics of migrants' remittances." Handbook of the economics of giving, altruism and reciprocity 2 (2006): 1135-1198.

Regmi, Gopal, and Clem Tisdell. "Remitting behaviour of Nepalese ruralto-urban migrants: Implications for theory and policy." Journal of Development Studies 38, no. 3 (2002): 76-94.

Sander, C. "Migrant remittances to developing countries: a scoping study."Bannock Consulting, London, 2003

Song, H., and Witt, S.F. Tourism Demand Modelling and Forecasting: Modern Econometric Approaches, Pergamon, Oxford, 2000.

Sri Lanka Bureau of Foreign Employment(SLBFE),2017, Annual Statistical Report of Foreign Employment 2017, http://www.slbfe.lk

Sri Lanka Bureau of Foreign Employment(SLBFE),2016, Annual Statistical Report of Foreign Employment 2016, http://www.slbfe.

Straubhaar, T. "The determinants of workers' remittances: The case of Turkey."Weltwirtschaftliches Archiv, 122(4), 1986, 728-740.

Swamy, Gurushri. "International Migrant Workers' Remittances: Issues and Prospects."Staff Working Paper 481.1981. 